McKee K, Community anchor housing associations: illuminating the contested nature of neoliberal governing practices at the local scale, Environment and Planning C: Government and Policy, 2015, 33 (5), pp. 1076-1091. Copyright (C) The Authors 2015. Reprinted by permission of SAGE Publications.

\title{
Community Anchor Housing Associations: illuminating the contested nature of neoliberal governing practices at the local scale
}

\begin{abstract}
In a period of fiscal austerity the mobilization of the voluntary and community sector has been pivotal to neoliberal public policy reforms. This is reflected in the emergence of a 'new localism', which seeks to encourage place-based communities to take responsibility for their own welfare through the ownership and management of community assets. In the UK these political narratives are encapsulated in the Prime Minister's Big Society agenda, which has been influential in the housing field, and has underpinned an emergent policy discourse constructing housing associations as community anchor organizations.
\end{abstract}

Drawing on the case study of the community-controlled housing association sector in Scotland, this paper illuminates the centrality of localism to contemporary technologies of neoliberal governance. Through an analytical focus on the agency of front-line housing professionals, it also adds to debates on 'ethnographies of government', which emphasize the situated messiness of projects of rule and the struggles around subjectivity.

Key words: empowerment, big society, governmentality, localism, voluntary sector, welfare reform 
[Type here]

\section{Introduction}

As Brenner and Theodore summarize, neoliberalism represents a "strategy of politicaleconomic restructuring", which has at its core the free-market processes of "deregulation, liberalization and state retrenchment" (2002: 342-3). Yet a critical examination of neoliberalism needs to see it as more than simply a political programme; it is a form of governmentality (or mentality of rule) that seeks "to govern without governing” by working through governable-subject's active agency (Read 2009: 29). As Rose (1999) underlines, this is a form of 'regulated freedom'; which on the one hand has liberatory possibilities, whilst also embodying regulatory potential (Cruikshank 1999; see also McKee 2011a, 2009). Through the promotion of self-governance, privatization and targeted interventions into public services, neoliberal governmentalities have transformed the relationship between the state and its citizens (see for example, Walters 2012; Miller and Rose 2008; Rose 1999; Dean 1999). The latest incarnation of this has been the revitalization of localism as a means of reconfiguring state-citizen relations, and devolving both autonomy and responsibility downwards from central government to 'empowered' citizens within community-based organizations at the local scale. Governments in the Antipodes, North America and Western Europe have endeavoured to roll back state involvement in welfare provision by instigating a more pluralistic model of welfare provision, which affords a greater role to the voluntary sector: a shift described as the 'voluntary turn' (Milligan and Conradson 2006). Voluntary sector organizations are identified not only as having an important role in service delivery (at reduced cost to the public purse), but have also been mobilized as key instruments for developing active citizenship and responsible 
[Type here]

community, through their close connection to the people and places that they serve. It is argued this reinvigoration of 'the local' represents a new mentality of rule that seeks to govern citizens through their bonds and attachment to place-based communities. As Macmillan and Townsend (2006: 29) highlight, this involves "specific constructions of space, scale and temporality, which have important consequences for the shape and structure of the emerging welfare state". Moreover, it reflects what Brenner and Theodore have termed the "evolving political-economic geographies of neoliberalism" (2002: 342), for whilst state retrenchment has been a feature of the neoliberal project since at least the 1980s it has occurred at different spatial scales, with the more recent 'voluntary turn' signifying a discursive privileging of the expertise and capacities of local people to take responsibility for their own welfare through the ownership and management of community assets.

In contemporary policy debates in the UK these ideas have been framed in terms of the Big Society. Although a somewhat nebulous concept it reflects the belief that the solutions to social problems lie within civil society at the local, community scalenot with 'big government' (Moore and McKee, In Press; Buser 2013; Wells 2011; Kisby 2010). As the UK Prime Minister, David Cameron has articulated:

"We believe that a strong society will solve our problems more effectively than big government has or ever will, we want the state to act as an instrument for helping to create a strong society. Our alternative to big government is the big society" (Cameron, 2009: no page number).

Intellectually, this political philosophy has drawn influence from the work of the social commentator Phillip Blond (2010), who critiques both state centralism and the 
[Type here]

excessive individualism of neoliberalism. The British welfare state in particular is denigrated in his book for eroding social values and creating a benefit dependency culture (popularized as the 'Broken Society' by government Ministers ${ }^{1}$ ). By contrast, a greater role is advocated for the voluntary and community sector, especially the traditions of co-operation and mutualism, as a means to strengthen social bonds and reorganize social life. The mobilization of local people and place-based communities in current UK policy debates therefore needs to be understood in the context of broader welfare narratives about the desired relationship between the state and its citizens. The imagined role of place-based communities, and the bonds that bind people locally, are pivotal to this.

This localist agenda has been particularly influential within housing policy, as reflected in the current political emphasis on the potential of not-for-profit housing associations in the UK to act as community anchor organizations, leading community development and regeneration at the neighborhood scale. To explore this issue in more depth, the paper focuses its empirical lens on the community housing sector in Scotland. Through thematic analysis of both policy documents and qualitative interviews with housing practitioners it illuminates the struggles around subjectivity, by emphasizing how front-line housing professionals challenged, contested and resisted the construction of housing associations (and the voluntary and community sector more broadly) as lead agents of local, place-based solutions in tackling the problems facing low-income neighbourhoods. This case study therefore provides insights into the localized production of neoliberal policy, and the capacity of governable-subjects (in this case front-line housing professionals) to challenge dominant policy narratives.

The paper begins by outlining key theoretical debates around neoliberal governmentalities, with a focus on the mobilization of the voluntary and community 
[Type here]

sector under 'new localism', before tracing the way in which these ideas have been evoked and mobilized in housing policy debates in the UK over recent decades, culminating in the Big Society. This discussion of the literature is followed by an outline of the research methods used in the paper. With reference to the case study of the community housing sector in Scotland, the paper then argues that the mobilization of local aspects of place, and the empowerment of communities to take over the ownership and management of front-line services, is central to the Scottish Government's regeneration strategy, with housing associations envisioned as playing a key role, and re-imagined as community anchor organizations. However, the qualitative data also shows that whilst interviewees' recognized the positive contribution organizations could make to this policy agenda, they were nonetheless critical of the government's approach, and expressed concern at a potential blurring of the boundaries between the public and voluntary sector. This highlights the importance of getting beyond a focus solely on rationalities of rule, and combining this with an analytical approach that gives voice and recognition to the perspectives, experiences and agency of those who might challenge the identities offered to them (see for example, McKee 2011a, 2009; Barnes and Prior 2009; Li 2007; Sharma 2006).

\section{Neoliberal Governmentalities, 'New Localism' and the 'Will to Empower'}

One of the legacies of neoliberalism has been a rise in neo-communitarianism, which emphasizes the contribution of the Third Sector and/or the social economy, as well as the role of grass-roots “self-organizing communities" (Jessop 2002: 455; see also Fyfe 2005). As Rose highlights community is a terrain of government between the state, the market and the individual; it represents an "extra-political zone of human relations" (2000: 6), with a moralizing emphasis on responsible conduct. It has occupied a pivotal 
[Type here]

role in the reconfiguration of state-citizen relations in recent decades as autonomy and responsibility for the welfare of citizens has been devolved downwards from the state to empowered citizens in their communities (McKee 2011a, 2009; Flint 2003; Imrie and Raco 2003).

In the current socio-political context of economic downturn and austerity within advanced liberal economies, we are again witnessing a 'revival of the local', manifest in a reinvigorated policy and political interest in localities, communities and places (Brenner and Theodore 2002; see also Buser 2013; Macleavy 2012; Raco 2005). Far from ushering in the 'irretrievable collapse' of neoliberalism (Peck et al 2009), it represents a technology of governance for managing the crisis within the neoliberal project by valorizing place-based policy solutions at the local scale (MacLeavy 2012; Peck and Tickell 1994). Whilst the extent to which the 'new localism' actually elevates the local as site of empowerment remains questionable, the mobilization of the voluntary and community sector is clearly attractive to governments as a means to reconstruct the post-war welfare settlement at reduced cost to the public purse. Civil society in this context is a "resource for the state, a reserve army of potential" (Morison 2000: 112). It is a means by which citizens can be governed through their active agency (at the local scale), and encouraged to take responsibility for their own life outcomes, and those of their fellow community members (Rose 2000; see also McKee 2009). However, it has also resulted in the Third Sector becoming further entangled in webs of governance within and beyond the state, potentially reducing its independence (Sharma 2006; see also Purkis 2012; McKee 2008). So whilst the 'new localism' may mean less direct government, this does not imply there is less governance per se (Walters 2012; Larner 2000; Rose 1999). It simply represents the latest form of what Rose (1999) has termed 'governing at a distance'. 
[Type here]

As Cruikshank (1999) underlines, such technologies of governance involve a close relationship between subjectivity and subjection. Relations of empowerment are themselves relationships of government, for they constitute and mobilize the governable-subject's capacity to act, and by doing so transform political subjectivity into an instrument of government. Such arguments are underpinned by a productive view of power, derived from Foucault (2003a, 2003b). They reject traditional conceptions of power as a negative act, instead illuminating the plethora of governmental strategies and techniques that seek to govern free individuals by attempting to shape their 'conduct' towards particular ends. This is a perspective on power that presupposes freedom (Miller 1987). For Foucault (2003a: 139) "the recalcitrance of will and the intransigence of freedom" are at the heart of the power relationship. Scholars interested in developing local and situated ethnographies of government have been particularly adept at illuminating these struggles around subjectivity (see for example, McKee 2011a; Li 2007; Sharma 2006, Inda 2005) - or what Tania Murray Li has described as the "inevitable gap between what is attempted and what is accomplished" by projects of rule (2007: 1). Usefully, these ethnographic studies go beyond the study of political rationalities of government, and instead, focus on "subject-making" (Inda 2005: 10). This directs attention not only to how governmental practices seek to shape and mobilize particular identities, but also towards how individuals negotiate these subject positions, and the gaps, contradictions and tensions that open up as a result. Uniting these ethnographic approaches is an analytical focus on materiality - what Inda describes as "the concrete manifestations of modern government [...] in very specific practices" (2005: 11). Understanding the active agency of front-line public and voluntary sector workers in the localized 
[Type here]

production of neoliberal policy is therefore crucial to avoiding characterizing neoliberalism in monolithic terms (Holloway and Pimlott Wilson 2012).

The next section of the paper traces the continuities and discontinuities in the way in which local, place-based communities have been constructed and mobilized in housing policy across the UK, for political projects need to be considered in their historical and spatial context if their complex and everyday materialities are to be fully understood (see for example, Lippert and Stenson 2011).

\section{The Mobilization of Community in Housing Policy in the UK}

Since the formation of the UK Coalition government in $2010^{2}$, the Big Society has become a key buzzword in political and policy agendas (Moore and McKee, In Press). It is a political philosophy that advocates that the solutions to social problems lie within civil society at the local, community scale (Wells 2011; Kisby 2010). In terms of policy solutions, it places a strong emphasis on the co-operative and mutual traditions, as well as other models of local decision-making and asset-ownership, as policy vehicles to transform public services. These ideas have been particularly influential within English housing policy, as evident in political support for Community Land Trusts and Community Self-Build projects as models of affordable housing (Moore and McKee 2012), and the potential of co-operative and mutual provision within the social rented sector (Handy and Gulliver 2010). The English Localism Act 2011 also proposes a number of controversial changes to local planning processes and the provision of social rented housing, through the introduction of 'flexible tenancies', the community 'right to challenge' and the community 'infrastructure levy' (CLG 2011; Jacobs and Manzi 2012; Kennett et al 2012). Housing reforms have, once again, become entangled in debates about welfare dependency - with strong community, as 
[Type here]

opposed to state support, being promoted as the solution to societal breakdown. Cabinet Minister Ian Duncan Smith's 'Broken Society' rhetoric is an illustrative example of this line of government thinking, which focuses on cultural as opposed to structural explanations of poverty (Hancock and Mooney 2012). The mobilization of housing associations as instruments of state policy is not however the novel invention of the Coalition government, as historical analysis highlights (Malpass 1999, 2000). Nonetheless, as this paper will unpack, the political rationalities underpinning their mobilization have changed.

Elsewhere in the UK there has been more scepticism towards the Big Society. Recent research on housing associations in Scotland saw it denounced as a banner under which "a number of right wing policies are being pursued" (McKee 2012: 12). Yet there is a long legacy of community ownership policy in Scotland - in both urban and rural settings - as manifest in legislative support for Community Land Trusts (Satsangi 2009), and the promotion of the community housing sector through 'community ownership' neighbourhood level housing stock-transfers (McKee 2012, 2011a, 2011b). The Scottish Government's (2012) consultation on the Community Empowerment and Renewal Bill (which seeks to support communities in making their own decisions and having their voices heard), and the Christie Commission (2011) into the reform of public services in Scotland (which emphasized the importance of community asset ownership) are further recent high profile policy examples. Despite differences in language and emphasis, local communities are being mobilized in policy terms across the UK. Political geography however has an important impact on the way in which policy discourses are constructed and mobilized in different ways, in different places (Raco 2003). Following devolution in 1999, responsibility for legislation in the public policy field now falls under the jurisdiction of the Scottish Parliament, Welsh and 
[Type here]

Northern Ireland Assemblies - with the UK government at Westminster continuing to legislate for England (Birrell 2009). This has resulted in significant policy divergence in some areas of public policy - including housing.

Nonetheless, within the housing arena a common thread has been the pivotal role accorded to housing associations as enablers of community-led solutions (McKee 2012). As a report from the UK think-tank Respublica underlined:

"Social housing is one of the largest capital investments by the state in our poorest communities. [Housing Associations] therefore have a critical role in the delivery of major public services and managing a robust and growing asset base. They $[\ldots]$ have immense potential as catalysts and anchors for community enterprise, as a focus for approaches to tackling worklessness and building resilience, and as vital sources of social capital and asset wealth" (Respublica 2011: 2).

With their independent asset-base and track record as regulated, sustainable social businesses, housing associations occupy an important mediating role between local people and the providers of other public services. They are lead agents of community development and regeneration at the local scale, providing a focal point for community activities and social enterprise (McKee 2012, 2011b). However, they are also heavily reliant on public funding to sustain their activities, and are subject to much greater regulation than other voluntary sector organizations because of this. As Deakin argues voluntary sector engagement with the state is "a perilous enterprise" (cited, in Purkis 2012: 96), not least because dispersed forms of governance continue to be paralleled by traditional hierarchical forms of control (McKee 2008), with associations criticized 
[Type here]

for simply being "an instrument of government policy" (Purkis 2012: 96), or what Wolch (1990) has termed, part of the 'shadow state' apparatus.

This ideological emphasis on community and the presumed benefits of devolving power downwards is not however new. The involvement of civil society in governing processes was central to the policy agenda of the previous New Labour administration (Jacobs and Manzi 2012; Somerville 2011; Raco 2005; Imrie and Raco 2003; Newman 2001), which was informed by ideas of communitarianism (Etzioni 1995) and a Third Way political philosophy (Giddens 1998). These ideas influenced housing and urban policies across the UK and included for example: the New Deal for Communities in England and the emergence of the community gateway model of housing stock transfer; community ownership of social housing in Scotland; and the growth of community housing mutuals in Wales. As Imrie and Raco (2003: 6) emphasize "active citizens, through the context of community, represent the mode of governance favoured in the pronouncements of the Labour government”. Communities of place were also important in the construction and implementation of housing policy before the New Labour government were elected in 1997, for ideas of localism have also been supported by the right of the political spectrum. In the 1980s Thatcher's Conservative government advanced a "new orthodoxy in housing management, based around the core concept of resident involvement"; although reducing the power of local authorities was as much an important driver as community empowerment per se (Jacobs and Manzi 2012: 5).

This clustering of "recurring features, tendential characteristics and family resemblances" reflects the "mongrel phenomenon" that is neoliberalism" (Peck et al 2009: 104-5). It is a governmental project that has developed in different places in different ways. The Big Society and localism therefore need to be seen in their 
[Type here]

historical and spatial context. As well as continuities in policy discourses, there are of course important differences between current and previous government's approaches, such as their differing relationship with, and financial support of, the Third Sector (Crisp et al 2009). This “cannot be divorced from political strategy" (Wells 2011: 52). Whilst New Labour emphasized co-governance and partnership working as a means to modernize public services, the Big Society evokes the voluntary and community sector as a means to attack 'big government', particularly the welfare state and its role in creating 'Broken Britain' (Ransome 2011). Indeed, the public expenditure climate for the voluntary and community sector in 2012 is quite different to what it was during the New Labour administration, with Third Sector organizations now enjoying significantly less state funding, with knock on effects for their sustainability and survival (Crowe et al 2010).

The next section of the paper provides more detail on the project, which underpins the empirical and theoretical arguments of this paper. This is followed by a discussion of the key themes arising from thematic analysis of the qualitative data.

\section{Research Methods}

Case study selection

This paper draws on research funded by a small grant from the Carnegie Trust for the Universities of Scotland. The aim of the study was to understand the relevance of the Big Society for housing policy in Scotland through a focus on community anchor housing associations. First coined in a Home Office report in 2004, 'community anchors' are community development organizations controlled by local people that operate within a defined geographical area: 
[Type here]

"Strong, sustainable community-based organizations can provide a crucial focus and support for community development and change in their neighbourhood and community. We are calling them 'community anchor organizations' because of the solid foundation they give to a wide variety of self-help and capacity building activities in local communities, and because of their roots within their communities" (Home Office 2004: 12)

Given the emphasis on place and community control within this definition, this study concentrated its empirical focus on Scotland's community-controlled housing association (CCHA) movement, which is geographically concentrated in the west of Scotland. CCHAs are small, community associations that are governed by a management committee comprising a majority of local people (for further details see McKee 2012; Clapham et al 1996). They are arguably the one of the strongest examples of community ownership in the UK today, and are underpinned by volunteering and place-based social capital that draw on and mobilize local social networks. They are much smaller in scale and have greater representation of tenants and residents on their governing bodies, compared to housing associations elsewhere in the $\mathrm{UK}^{3}$ (see for example, McKee 2011a, 2011b; Goodlad 2000; Clapham et al 1996). Moreover, they have an established track record of neighbourhood renewal and social enterprise in low-income neighbourhoods, and are much more then just landlords, for they provide a plethora of services to benefit their local areas and the people residing within it (McKee 2012; see also Mullins et al 2012; Respublica 2011). Indeed, it is the small size and geographical focus of CCHAs that makes the Scottish context particularly interesting when trying to understand and unpack debates around localism. 
[Type here]

\section{Fieldwork}

Fieldwork for this project took place between January and March 2012 and comprised two elements:

- Expert interviews were conducted with housing practitioners across two phases:

o Interviews were held with senior staff from eight CCHAs. Organizations were selected that were already strong, positive examples of community anchor housing organizations

Interviews were held with senior staff from five national membership organizations, which provide support and representation to Scottish housing associations and community anchor organizations. These organizations have been anonymized to protect confidentiality.

- Analysis of key policy documents at the national and local level, as well as grey literature from the case study organizations.

The decision to focus on housing professionals was a critical one. The Foucauldianinspired social policy literature highlights the ways in which welfare professionals are inculcated in governing practices. Yet the active agency of public and voluntary sector workers is often neglected (for exceptions, see Flint 2012; Holloway and PimlottWilson 2012; Barnes and Prior 2009). This is a significant gap for these individuals have a key role to play in reinterpreting neoliberal policy through their practice. Understanding how they challenge and contest the "identities that are offered to or imposed on them by government" (Barnes and Prior 2009: 3) thus opens up a critical space to explore the struggles around subjectivity. Although only a small exploratory 
[Type here]

project, this study nonetheless offers an incisive case study through which to further develop our understanding of the local production of neoliberal policies.

\section{The Relevance of the Big Society for Housing Associations in Scotland}

Through thematic analysis of qualitative interviews and policy documents this section of the paper illustrates how the 'new localism' has resulted in the construction and mobilization of housing associations as community anchor organizations, ideally placed to support community asset-ownership and regeneration at the neighourhood level. Yet by emphasizing the ways in which front-line housing professionals actively contested dominant policy narratives emanating from the Scottish Government, this section also underlines how 'welfare professionals' relate policy narratives to their own practice, and thus shape and contest the local implementation of neoliberal policies.

\section{Mobilizing community and the 'local' aspects of place}

The Scottish Government launched its regeneration strategy: Achieving a Sustainable Future in December 2011. Central to tackling the challenges facing Scotland's most disadvantaged communities is a stronger focus on community-led regeneration, that is, on mobilizing funding and other support mechanisms to enable communities to better help themselves address their social, economic and environmental problems:

"[O]ur collective approach is not on the deficits of an area but rather the assets that communities have. To support communities to be sustainable we must identify the assets that exist - economic, physical and social - and use these assets to deliver sustainable, positive change" (SG 2011: 12). 
[Type here]

This strategy reinforces the recommendations of the Christie Commission (2011) on the future delivery of public services in Scotland, which emphasized the importance of community asset-ownership in revitalizing and transforming Scotland's public services:

"Our evidence demonstrates the need for public services to [...] become transparent, community-driven and designed around users' needs. They should focus on prevention and early intervention [and] [...] work more closely with individuals and communities to understand their circumstances, needs and aspirations and enhance self-reliance and community resilience" (Christie Commission 2011: 22).

Central to both documents is the policy assumption that the 'problems' facing Scotland's most fragile communities cannot be tackled without public sector agencies working together with local people, and communities taking responsibility for developing their own solutions through the control and ownership of local assets and services. No longer is the state (either at the national or local scale) expected to solve all of society's problems; rather responsibility is being devolved downward through maximizing community engagement and mobilizing local knowledge, capacities and skills (McKee and Cooper 2008; Rose 2000; Cruikshank 1999). In a period of global financial crisis and constrained public sector spending, the mobilization of 'the local' is now more than ever being constructed in policy terms as a panacea for social problems: 
[Type here]

"Community-led regeneration is about local people identifying for themselves the issues and opportunities in their areas, deciding what to do about them, and being responsible for delivering the economic, social and environmental action that will make a difference. It is a dependent on the energy and commitment of local people themselves and has a wide range of benefits" (SG 2011: 20: my emphasis added).

"The pressure on budgets is intense and public spending is not expected to return to 2010 levels in real terms for 16 years. In addition, new demographic and social pressures will entail a huge increase in the demand for public services. The economic downturn will also intensify and prolong demand. Unless Scotland embraces a radical, new, collaborative culture throughout our public services, both budgets and provision will buckle under the strain" (Christie Commission 2011: viii).

As the regeneration strategy highlights Scotland already has a rich and diverse voluntary and community sector led by local 'anchor' organizations that drive forward a plethora of community development and regeneration activities (SG 2011; see also McKee 2012). There remains however a perception within government that such organizations are not fulfilling their potential, hence the push to re-imagine and valorize them as 'anchor organizations' within policy narratives. In order to build on current success and activity in the sector the regeneration strategy introduced the new People and Communities Fund, which will provide circa $£ 8$ m per annum from 2012-15 to build capacity for community-led regeneration activities. An explicit aim of this fund is to support local anchor organizations and community asset-ownership. The focus on 
[Type here]

'anchor' organizations, which are community-based and community-controlled (McKee 2012; Home Office 2004), connects to the long legacy of community ownership policy in Scotland (McKee 2011a; Satsangi 2009), which is being developed further through the Scottish Government's Community Empowerment and Renewal Bill that expected to be introduced to the Scottish Parliament in 2013/14. This highlights how policy thinking on community-based approaches to service provision and renewal now transcends the housing sector. It is in sharp contrast to the individualization and conditionality that are central to ongoing welfare reforms in the UK, as manifest in the introduction of Universal Credit ${ }^{4}$ and reform of other state welfare benefits (Hancock and Mooney 2012; Jacobs and Manzi 2012), and has strong synergies with the traditions of co-operation and mutualism encapsulated by the Big Society. Although these ideas are not new, they have experienced resurgence in an era of constrained public spending, with 'the local' now being firmly imagined as the appropriate scale for policy intervention, service delivery and partnership working across the public, private and community sectors.

Interviews with housing professionals highlight that these discourses regarding the presumed benefits of communities leading the regeneration of Scotland's most deprived neighbourhoods (as previously outlined) have strong resonance at the grassroots level. There was widespread support amongst those interviewed for communityled solutions, and for encouraging local people to do things for themselves. In particular, housing practitioners regarded the idea of community anchor organizations, which was mentioned throughout the regeneration strategy, as a positive one to characterize and promote the work of the sector: 
[Type here]

"It does seem astonishing, because if you talk about the Big Society and anchor organisations I mean the only examples that people can really highlight are housing associations. Look at the track record!” (Interview 10, CCHA Senior Officer)

It was a metaphor that strongly connected with their practice, especially their aspirations to play a greater role in minimizing the negative impacts of public sector cuts, by protecting and continuing to provide services to local people. Interviewees were keen to stress associations' local asset-base, place-based focus and strong relationship with their communities and others partners. Moreover, they highlighted the huge energy in the sector, and the track-record associations had in terms of transforming peoples' lives and the communities in which they were based. A recurring theme was that associations were 'more than just landlords' dealing with housing management and the physical renewal of their properties. They had evolved to become anchor organizations concerned with the wider social, economic and environmental circumstances within their geographical area of operation. As the senior officer from one association reflected:

"You need to have the appetite to do this type of work; not all associations make the connections. I don't see us primarily as a housing organization. We are a community organization that happens to be a landlord. It's a different mindset” (Interview 4, CCHA Senior Officer). 
[Type here]

As the Word Cloud in Figure 1 (constructed from a content analysis of practitioner interviews) highlights, associations already provide directly, or through partnership with others, a diverse range of community development activities targeted towards helping local people build their skills, find jobs, engage in volunteering, and improve their health and well-being. They are key focal points in their communities for local activities and services.

\section{[Insert Figure 1 here]}

Moreover, already having a governance structure premised on the principles of community ownership made them ideally placed to assume this anchor role, in contrast to other community organizations. CCHAs in Scotland are owned and managed by local people, being governed by a management committee comprising of a majority of tenants and residents:

"If you look at the definition of [community anchors], it could be forests, it could be a recycling organization, it could be a faith based group in some communities. So it doesn't have to be a housing association. It just so happens that in a lot of areas the most robust and sensible organization is the housing association” (Interview 2, Senior Officer, Membership Organization).

The 'anchor' metaphor, which emphasizes local aspects of place, is central to the way in which community organizations are being constructed as key policy vehicles in delivering place-based, community-led solutions. Crucial here is not only the mobilization of place-based identity, but also an emphasis on community-control, and 
[Type here]

the capacity for local people to affect change within their neighbourhoods (McKee 2011a). This is a strong example of what Cruikshank (1999: 68) describes as 'the will to empower': a mode of governing which aims to "act upon others by getting them to act in their own interest". Empowerment in this context is itself a power relationship, which has regulatory as well as liberatory possibilities (McKee and Cooper 2008). As Cruikshank (1999: 39) underlines it works by encouraging citizen-subjects to actively participate for, it "cannot force its interest, but must enlist the willing participation of individuals in the pursuit of its objects". Therefore, whilst 'empowerment' may bring positive benefits for people and places, it is nonetheless a relationship of power that needs to be subject to critical scrutiny. It constructs and evokes a particular role for these organizations, as reflected in policy thinking and proposed solutions.

\section{Practitioner agency and the struggles around subjectivity}

Although housing professionals embraced the notion of anchor organizations and saw its relevance for the housing association sector, they did not do so uncritically. This highlights the importance of exploring practitioner agency, and therefore the potential of governable-subjects to challenge, contest and resist top-down policy discourses emanating from government. Firstly, despite their support for community-led solutions practitioners nonetheless dismissed the Big Society label as irrelevant, describing it as an "English and Tory concept" (Interview 12, Senior Officer, Membership Organization). In particular, interviewees were keen to stress that the principles of community empowerment, community asset-ownership and place-based volunteering were not novel, and indeed, there was much that the rest of the UK could learn from Scotland's longstanding experience and expertise in these fields: 
[Type here]

"I don't think anybody in Scotland actually looks at the Big Society as being an issue. There's all these things going on but they don't necessarily intersect, they co-exist but they don't actually connect with each other" (Interview 13, Senior Officer, Membership Organization”.

Even amongst those who favoured the anchor label there was concern about adopting “someone else's term” (Interview 9, CCHA Senior Officer), as well as scepticism of the need for a new label to "dress up what they did" (Interview 5, CCHA Senior Officer), given the long and successful history of the community housing sector. Practitioners felt the 'anchor' idea was an artificial construction propagated by government, as opposed to one that had arisen organically from within the movement itself. Nonetheless, there was an awareness that connecting with this agenda potentially opened doors to important avenues of funding for community development and regeneration. This was recognized as crucial in the current era of constrained public sector resourcing, in which social housing budgets have been cut by over 40 per cent. It reflects the economic imperatives driving the Big Society policy rhetoric.

Secondly, practitioners were highly critical of the expectations being placed on Third Sector organizations through the emphasis on community-led solutions. There was concern that this may lead to a blurring of the boundaries between voluntary and public sector provision, with Third Sector organizations increasingly expected to fill the gaps in social welfare provision left by state retrenchment in an era of public sector cuts. By contrast housing associations saw their role as supporting, not replacing, existing public services, by providing an interface between the state and local people:

"In my book it is not about the housing organization replacing the public 
[Type here]

services $[\ldots]$ to me it is about something that helps the public services work in a way that is more locally appropriate and more locally sensitive" (Interview 12, Senior Officer, Membership Organization).

Expecting associations to do more in terms of community regeneration was deemed problematic, not least because they are also facing significant threats to their income streams because of budget reductions, and the potential impact of Housing Benefit reforms, a social security benefit which accounts for over 50 per cent of the income stream of the sector in Scotland (for further discussion on reforms Kennett et al 2012). Interviewees also reflected that the many of the challenges facing Scotland's most deprived neighbourhoods, which include poverty, low-educational attainment, illhealth, and unemployment were the product of structural inequalities that required national level policy solutions designed to redistribute wealth. Area-based solutions, although important, on their own were perceived as ineffective in tackling these social problems (for further discussion, see McKee 2011b), and housing associations expressed frustration at government expectations that they could (and should) solve all these problems locally. This underlines a significant tension between government and voluntary and community sector organizations about the appropriate scale at which policy interventions are to be targeted. Moreover it reflected serious concerns about the mobilization of the sector as a "putative solution" to tackling the challenges facing Scotland's low-income neighbourhoods, and the extent to which this rescaling of policy interventions might lead to the "localization of policy failure" (Macmillan and Townsend 2006: 19-22)

Thirdly, and related to the previous point, associations still identified funding constraints as a major barrier to developing their anchor role. Whilst they maintained 
[Type here]

they had the potential and aspiration to do more on the community regeneration front, they argued there was a lack of targeted financial resources from government to make this happen. This reflects a tension between policy narratives as articulated in strategic policy documents, and the reality of delivering social programmes in 'hard times'. As the Chief Executive of one membership organization commented:

"It's fine to say that housing associations can and should do all these things but how exactly [...] there's no money" (Interview 13, Senior Officer, Membership Organization).

Although the introduction of the People and Communities fund was welcomed, there was concern that the practical details of the scheme (including eligibility) were lacking, and that the fund represented more competition for fewer resources than its previous incarnation (the Wider Role Fund, which was only open to housing associations). The language of community anchors was therefore interpreted as a mask for state retrenchment, for alongside the devolution of autonomy and control, responsibility for local problems was also being delegated downwards from government to local people and community organizations (Rose 1999; McKee 2011b). This concern about state retrenchment needs to be understood in the wider context of welfare reform in the UK. For example, changes to eligibility and payment of Housing Benefit: a social security benefit that helps low-income households meet their rent, has fuelled concerns that it will lead to the displacement of low-income groups from areas with higher rents, as well as jeopardise housing associations' rental income by ending direct payments to landlords (for further discussion see, Jacobs and Manzi 2012; Kennett et al 2012). Senior officers were only too acutely aware of the wider social, political and economic 
[Type here]

context in which their organizations had to operate, and this underpinned their critical appraisal of the narrative about anchor organizations emanating from government.

Finally, interviewees stressed a lack of political support from government at both the local and national scale, which inhibited their ability to embrace their anchor role. There was a strong perception that government (especially civil servants) did not really understand the social value of housing associations, and favoured other types of community organizations instead. This left practitioners feeling they were receiving a mixed message. Moreover, whilst housing professionals welcomed the increased profile and recognition that came with the policy emphasis upon localism, they remained concerned that this narrative did not adequately reflect current fiscal conditions. Whilst this might seem a contradictory viewpoint, given the policy support for anchor organizations previously outlined, it reflects a belief amongst associations that government expected too much from them, as well as perceived tensions between different aspects of housing and regeneration policy. For example, the Scottish Housing Regulator ${ }^{5}$ expressed much more caution about the potential for associations to use their housing assets for the wider good of the community, as compared to the policy rhetoric embedded in the regeneration strategy. As one interviewee commented:

“The Regulator [...] certainly doesn't send out a positive message about using your assets in a different way [...] there will be a concern that it's not seen in regulating terms as part of their core [housing] business" (Interview 12, Senior Officer, Membership Organization).

This example underlines the importance of not treating 'the state' as a homogenous entity, with all actors singing from the same hymn sheet. These tensions also emphasize 
[Type here]

the importance of contextualizing these debates within the wider changes in the social housing sector, and the ongoing UK welfare reform agenda.

\section{Conclusion}

This paper has sought to illuminate the particularities of governing practices, and therefore the struggles around subjectivity, through an empirical focus on localism and the Big Society within Scottish housing policy. As the qualitative data highlights a strong policy discourse has emerged which emphasizes the pivotal role of housing associations as key enablers in community-led solutions within low-income neighbourhoods. This represents a contemporary example of 'governing the local', which mobilizes place-based communities and local identities to encourage individuals and community-based organizations to take a lead role in transforming their neighbourhoods. Central to this are technologies of governance that encourage community anchor organizations, and the local people they represent, to act in their own interest. This is, as Cruikshank (1999) highlights, a strong example of the 'Will to Empower'. It is premised on mobilizing local people to actively engage and participate, whilst at the same time responsibilizing them for their future welfare. A means of legitimating the neoliberal project in 'hard times' these technologies of governance underline the dynamic and adaptive nature of neoliberalism as a regime of socio-economic governance (Peck et al 2009).

The theoretical arguments of this paper also highlight how qualitative research at the micro-level has a pivotal role to play in building our understanding of governing beyond the state. Not least because it allows us to combine critical analysis of rationalities of rule, with a more ethnographic endeavour that brings into analytical focus the voices and experiences of those who have been imagined and constructed as 
[Type here]

particular types of 'subjects'. This permits greater scrutiny to be accorded to the way in which governmentalities play out in different ways in different places, and at different times. The importance of a geographical lens is why this study has focused specifically on social housing policy in Scotland, for undoubtedly policy developments elsewhere in the UK would follow a different path. Methodologically and empirically, 'ethnographies of government' have much to offer, for they enable a more nuanced understanding of the complex power relationships inherent in neoliberal projects of rule.

In terms of implications for policy, this paper has underlined how thinking has changed, with housing associations now cast as more than just landlords concerned with housing management. Rather they are being re-imagined as anchor organizations, and expected to play a key role in neighbourhood renewal and local service provision. Important in the Scottish context has been the influence of the Christie Commission (2011) and its emphasis on community-assets as a means to renew and revitalize public services; but a further driver has been the financial reality of operating in an era of constrained public sector spending, which has forced many social landlords to diversify their activities beyond their traditional housing management role. These policy lessons have broader international transfer given the global reach of the economic downturn and the challenges facing national governments across the advanced economies, which are now under fiscal pressure to reduce budgets and implement austerity measures. Here, the language of community anchors helps us to understand the imagery at play, and how these organizations are been evoked in rhetorical terms. Further research in this field is however needed to develop, both theoretically and empirically, the concept of community anchor organizations, particularly with regards to how it relates to 
[Type here]

neoliberalism and the emergent 'new localism'. It is hoped that this paper will act as a starting point for further debate, discussion and study.

\section{Endnotes}

${ }^{1}$ The Broken Society is a political narrative popularized by the UK Conservative Party, particularly the Centre for Social Justice. It argues Britain is 'broken' because troubled families and welfare dependency have contributed to moral breakdown and social problems. These arguments draw attention to individual personal failings and irresponsibility as drivers for poverty, and have points of connection with previous underclass debates, which predominated in the 1980s and 1990s.

${ }^{2}$ In 2010 a coalition government was formed in the UK between the Conservative Party and the Liberal Democrats, due to the failure of any one political party to secure an overall majority in the general election.

${ }^{3}$ Local residents comprise around 50 per cent of governing body members in Scottish Housing Associations. This figure is higher in small, urban community housing associations where local people generally comprise the majority of board members. This is distinctive from the more 'professionalized' nature of governing bodies in associations across the rest of the UK, which have much less resident representation. ${ }^{4}$ Universal Credit is a new single payment for people out of work or on a low-income in the UK. It replaces a range of means-tested benefits and tax credits. Concerns have however been raised about heavy reliance on one IT system, the income caps and punitive measures embedded in the system, as well as potential work disincentives.

${ }^{5}$ The Scottish Housing Regulator is the independent regulator for not-for-profit social landlords in Scotland, which includes housing associations/co-operatives and local 
[Type here]

authority landlords. Established in April 2011 its role is to represent and safeguard the interests of current and future tenants.

\section{Acknowledgements}

This project was funded by a small grant from the Carnegie Trust for the Universities of Scotland. Thanks to John Flint, Tom Moore, Pauline McLoughlin and Michelle Brady for comments on an earlier version. 
[Type here]

\section{References}

Barnes M, and Prior D, 2009 Subversive Citizens: power, agency and resistance in public services (Bristol: Policy Press)

Birrell D, 2009 The Impact of Devolution on Social Policy (Bristol: Policy Press)

Blond P, 2010 Red Tory: how the left and right have broken Britain and how we can fix it (London: Faber and Faber)

Brenner N, and Theodore N, 2002, "Preface: from the 'new localism' to the spaces of neoliberalism" Antipode 34(3) 349-379

Buser M, 2013, “Tracing the Democratic Narrative: big society, localism and civic engagement" Local Government Studies 39(1) 3-21

Cameron D, 2009 The Big Society: Hugo Young lecture, $9^{\text {th }}$ November 2009: http://www.conservatives.com/news/speeches/2009/11/david_cameron_the_big_socie $\underline{\text { ty.aspx }}$

Christie Commission, 2011 Commission on the Future Delivery of Public Services (Edinburgh: Scottish Government): http://www.scotland.gov.uk/About/Review/publicservicescommission

Clapham D, Kintrea K, and Kay H, 1996, "Direct Democracy in Practice: the case of 'community ownership' housing associations" Policy and Politics 24(4) 359-374 
[Type here]

Communities and Local Government (CLG), 2011 A Plain English Guide to the Localism Act:

http://www.communities.gov.uk/documents/localgovernment/pdf/1896534.pdf

Crisp R, Macmillan R, Robinson D, and Wells P, 2009, "Continuity or Change: considering the policy implications of a Conservative government" People Place and Policy Online 3(1) 58-74

Crowe M, Dayson C, and Wells P, 2010, "Prospects for the Third Sector" People Place and Policy Online 4(1) 29-32

Cruikshank, B, 1999 The Will to Empower: democratic citizens and other subjects (Ithaca and London: Cornell University Press)

Etzioni A, 1995 The Spirit of Community: rights, responsibilities and the communitarian agenda (London: Fontana Press)

Flint J, 2012, “The Inspection House and Neglected Dynamics of Governance: the case of domestic visits in family intervention projects" Housing Studies 27(6) 822838

Flint J, 2003, “Housing and Ethopolitics: constructing identities of active consumption and responsible community" Economy and Society 32(3) 611-629 
[Type here]

Foucault M, 2003a, “The Subject and Power", pp. 126-144, in The Essential Foucault: selections from Essential Works of Foucault, 1954-1984 Eds P Rabinow and N Rose (New York: The New Press)

Foucault M, 2003b, “Truth and Power", pp. 300-318, in The Essential Foucault: selections from Essential Works of Foucault, 1954-1984 Eds P Rabinow and N Rose (New York: The New Press)

Fyfe N, 2005, “Making Space for 'Neo-communitarianism'? The Third Sector, State and Civil Society in the UK" Antipode 37(3) 536-557

Giddens A, 1998 The Third Way (Bristol: Policy Press)

Goodlad R, 2000, From Public to Community Housing: Scottish experiences and prospects. Paper presented at IPPR Future of Social Housing Forum: http://www.ippr.org/uploadedFiles/ipprcommissions/Scottish_experiences_and_prosp ects.pdf

Hancock L, and Mooney G, 2012, “'Welfare Ghettoes' and the 'Broken Society': territorial stigmatization in the contemporary UK" Housing Theory and Society 30(1): $46-64$

Handy C, and Gulliver K, 2010, Mutualism Rising? Housing's Vital Role in the 'Big Society':

http://clients.squareeye.net/uploads/compass/documents/CTP66HandyMutualism.pdf 
[Type here]

Holloway S L, and Pimlott-Wilson H, 2012, "Neoliberalisation, policy localization and idealized subjects: a case study on educational restructuring in England" Transactions of the Institute of British Geographers 37(4) 639-654

Home Office, 2004 Firm Foundations: the government's framework for community capacity building (HMSO: London)

Imrie R, and Raco M, 2003 Urban Renaissance: New Labour, community and urban policy (Bristol: The Policy Press)

Inda J X, 2005, “Analytics of the Modern: an introduction”, pp 1-20 in Anthropologies of Modernity: Foucault, governmentality and life politics Ed J X Inda (Oxford: WileyBlackwell)

Jacobs K, and Manzi T, 2012, 'New Localism, Old Retrenchment: the 'big society', housing policy and the politics of welfare reform" Housing Theory and Society 30(1): 29-45

Jessop B, 2002, “Liberalism, Neoliberalism, and Urban Governance: a state-theoretical perspective" Antipode 34(3): 452-472

Kennett P, Forrest R, and Marsh A, 2012, "The Global Economic Crisis and the Reshaping of Housing Opportunities" Housing Theory and Society 30(1): 10-28 
[Type here]

Kisby B, 2010, “The Big Society: power to the people?” The Political Quarterly 81(4): 484: 491

Larner M, 2000, "Neoliberalism: policy, ideology, governmentality" Studies in Political Economy 63: 5-25

Li T M, 2007 The Will to Improve: governmentality, development and the practice of politics (Durham and London: Duke University Press)

Lippert R, and Stenson K, 2011, “Advancing Governmentality Studies: lessons from social constructionism" Theoretical Criminology 14(4): 473-494

MacLeavy J, 2012, “The Lore of the Jungle: neoliberalism and statecraft in the globallocal disorder (revisiting Peck and Tickell)" Area 44(2): 250-253

Macmillan R, and Townsend A, 2006, “A 'New Institutional Fix' The 'Community Turn' and the Changing Role of the Voluntary Sector", pp 15-32 in Landscapes of Voluntarism: new spaces of health, welfare and governance Eds C Milligan and D Conradson (Bristol: Policy Press)

Malpass P, 1999, "Housing Associations and Housing Policy in Britain since 1989”, Housing Studies 14(6): 881-893

Malpass P, 2000 Housing Associations and Housing Policy: a historical perspective (London: Palgrave Macmillan) 
[Type here]

McKee K, 2012 Housing Associations and the Big Society: lessons from Scotland's community housing sector (University of St Andrews: St Andrews)

McKee K, 2011a, "Sceptical Disorderly and Paradoxical Subjects: problematising the 'will to empower' in social housing governance" Housing Theory and Society 28(1): 118

McKee K, 2011b Glasgow and West of Scotland Forum of Housing Associations' Response to the Scottish Government's Regeneration Discussion Document: Building a Sustainable Future (Glasgow and St Andrews: GWSF and University of St Andrews)

McKee K, 2009, "Post Foucauldian Governmentality: what does it offer critical social policy analysis?" Critical Social Policy 29(3): 465-486

McKee K, 2008, “Transforming Scotland's Public Sector Housing through Community Ownership: the re-territorialisation of housing governance" Space and Polity 12(2): $183: 196$

McKee K, and Cooper V, 2008, “The Paradox of Tenant Empowerment: regulatory and liberatory possibilities" Housing Theory and Society 25(2): 132-146

Miller P, and Rose N, 2008 Governing the Present (Cambridge: Polity Press)

Miller P, 1987, Domination and Power (London: Routledge \& Kegan Paul) 
[Type here]

Milligan C, and Conradson D, 2006, "Contemporary Landscapes of Welfare: the 'voluntary turn'?” pp 1-15 in Landscapes of Voluntarism: new spaces of health, welfare and governance Eds C Milligan and D Conradson (Bristol: Policy Press)

Moore T, and McKee K, In Press, "The Ownership of Assets by Place-Based Community Organisations: political rationales, geographies of social impact and future research agendas", Social Policy and Society

Moore T, and McKee K, 2012, “Empowering Local Communities? An International Review of Community Land Trusts (Policy Review)" Housing Studies 27(2): 280-290

Morison J, 2000, "The Government-Voluntary Sector Compacts: governance, governmentality and civil society" Journal of Law and Society 27(1) 98-132

Mullins D, Cziscshke D, and van Bortel G, 2012, "Exploring the Meaning of Hybridity and Social Enterprise in Housing Organisations", Housing Studies 27(4): $405-417$

Newman J, 2001 Modernizing Governance: New Labour, policy and society (London: Sage)

Peck J, Theodore N, and Brenner N, 2009, "Postneoliberalism and its Malcontents" Antipode 41(1) 94-116 
[Type here]

Peck J, and Tickell A, 1994, “Jungle Law Breaks Out: neoliberalism and global-local disorder" Area 26(4): 317-326

Purkis A J, 2012, "Big Society Contractors? Big Questions for Voluntary Organizations" Voluntary Sector Review 3(1) 93-101

Raco M, 2005, "Sustainable Development, Rolled-Out Neoliberalism and Sustainable Communities" Antipode 37(2) 324-347

Raco M, 2003, “Governmentality, Subject-Building and the Discourses and Practices of Devolution in the UK" Transactions 28(1) 75-95

Ransome P, 2011, “"The Big Society Fact or Fiction? - a Sociological Critique” Sociological Research Online 16(2) 18

Read J, 2009, “A Geneaology of Homo-Economicus: neoliberalism and the production of subjectivity" Foucault Studies 6: 25-36

Respublica, 2011 At the Crossroads, retrieved 20/02/2012: http://www.respublica.org.uk/documents/lrb_ResPublica\%20At\%20the\%20Crossroad s\%20Executive\%20Summary.pdf

Rose N, 2000, "Community, Citizenship and 'The Third Way", American Behavioural Scientist 43: 1395-1411 
[Type here]

Rose N, 1999 Powers of Freedom: reframing political thought (Cambridge: Cambridge University Press)

Satsangi M, 2009, “Community Land Ownership, Housing and Sustainable Rural Communities" Planning Practice and Research 24(2) 251-262

Scottish Government, 2012 A Consultation on the Proposed Community Empowerment and Renewal Bill (Edinburgh: Scottish Government): http://www.scotland.gov.uk/Publications/2012/06/7786

Scottish Government, 2011 Achieving a Sustainable Future: regeneration strategy (Edinburgh: Scottish Government)

Sharma A, 2006 Logics of Empowerment: development, gender and governance in neoliberal India (Minneapolis and London: University of Minesota Press)

Somerville P, 2011 Understanding Community: politics, policy and practice (Bristol: Policy Press)

Walters W, 2012 Governmentality: critical encounters (London: Routledge)

Wells P, 2011, "Prospects for a Big Society?” People Place and Policy Online 5(2): 50-54 


\section{[Type here]}

Wolch J, 1990 The Shadow State: government and voluntary sector in transition (New York: the Foundation Centre) 
[Type here]

Figure 1: Word Cloud of Case Study Organization's Activities

$$
\begin{aligned}
& \text { health promotion volunteering } \\
& \text { sports-facilities employability } \\
& \text { community-arts youth projects } \\
& \text { social events } \begin{array}{c}
\text { co-location } \\
\text { transport caffe welfare-rights }
\end{array} \\
& \text { childcare social-history communiry-educt } \\
& \text { meeting space community-garden } \\
& \text { kesure-facilitics community-hub greenspace } \\
& \text { social inclusion projects } \\
& \text { money-advice }
\end{aligned}
$$

